International Journal of Bioscience and Medicine
(ISSN:2575-7814)

\title{
AROMATHERAPY: PROPHYLACTIC AND THERAPEUTIC APPROACH TO DISEASES OF THE RESPIRATORY SYSTEM
}

\author{
Alan Lucena de Vasconcelos ${ }^{1}$, De Vasconcelos, A.L'; Alex Lucena de Vasconcelos ${ }^{2}$ \\ MSc. Pharmacist of the Clinical Research Group at Instituto de Ensino e Pesquisa Alberto Ferreira \\ da Costa. ZIP Code: 52.010-075 - Recife, PE - Brazil'. PhD Pharmacist Professor of the Pharmacy \\ Department at the Pernambuco Health College - FPS ${ }^{2}$
}

\begin{abstract}
Infectious diseases are a significant public health challenge due to the increasing recognition of new infectious agents and the resurgence of infections until recently controlled. These infectious illnesses constitute many hospital admissions, mainly respiratory focus, which requires high-cost therapy. One of the strategies to prevent injuries leading to hospitalization is reducing the body's inflammatory response. Thus, aromatherapy seems to be a useful adjuvant therapeutic tool due to the essential oils' synergistic action with proven anti-inflammatory and antimicrobial properties. Hence, this study proposes an integrated review of the literature on aromatherapy as a tool to be used in prophylaxis and therapy in respiratory system disorders. After passing the criteria of exclusion and content analysis, a set of 124 articles narrowed to 44 articles that support the anti-inflammatory properties of the sesquiterpenes, such as the farnesol. This substance treats the respiratory system and is present in Cymbopogon nardus, Cymbopogon flexuosus, and Rosa damascena. Caryophyllene and its derivatives are present in Syzygium aromaticum, Rosmarinus officinalis, and Cannabis sativa. Besides, $\alpha$-bisabolol and chamazulene present in Matricaria recutita and Achillea millefolium. Other oils have antibiotic properties that act against gram-positive and gram-negative bacterias according to their constitution's complexity and interaction with these microorganisms. In this context, some species such as Cinnamomum zeylanicum, Citrus hystrix, Cymbopogon Citratus, Eucalyptus globulus, Eucalyptus odorata, Juniperus communis, Lavandula angustifólia, Lavandula intermedia, Melaleuca leucadendra, Mentha piperita, Pinus sylvestris, Syzygium aromaticum, and Thymus vulgaris are in the spotlight. Several studies, both in vitro and in vivo, have demonstrated the potential use of essential oils alone or combined with oils from other species as a strategy for the prevention of respiratory diseases and potentiation of standard therapies. This approach is possible due to the synergistic effects of substances with bioactive potential such as sesquiterpenes, monoterpenes, and phenylpropanoids.
\end{abstract}

Keywords: essential oil, respiratory diseases, aromatherapy.

*Correspondence to Author:

Alex Lucena de Vasconcelos

PhD Pharmacist Professor of the Pharmacy Department at the Pernambuco Health College - FPS

How to cite this article:

Alan Lucena de Vasconcelos, De Vasconcelos, A.L; Alex Lucena de Vasconcelos. AROMATHERAPY: PROPHYLACTIC AND THERAPEUTIC APPROACH TO DISEASES OF THE RESPIRATORY SYSTEM.International Journal of Bioscience and Medicine, 2021; $4: 15$.

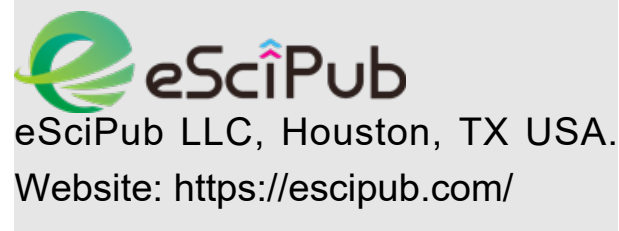




\section{INTRODUCTION}

Infectious diseases are a significant public health challenge due to the increasing recognition of new infectious agents and the resurgence of infections until recently controlled. They constitute almost half $(47 \%)$ of hospital admissions in pediatric patients [31].

When evaluating patients in more critical conditions such as those hospitalized in intensive care units, there is a probability of 5 to 10 times of contracting infections, especially respiratory infections, representing about $20 \%$ of a hospital's total infections [38].

Evidence related to nosocomial infections in Brazil shows higher rates when compared to other countries. The evaluation performed from the Extended Prevalence of Infection in Intensive Care II (EPIC II) study exposed that among patients hospitalized in Brazil, $62 \%$ had an infectious condition, which significantly represents a higher prevalence when compared to the values observed for North America (percentage) and Europe (percentage) [39].

According to the study, the most frequent site of infection is the respiratory $(71.2 \%)$, followed by urinary tract infection (16.6\%) and abdomen (13.4\%); $10.1 \%$ had bloodstream infection. The bacterial microorganisms most commonly associated with respiratory-related infections include Streptococci pneumoniae, Haemophilus influenzae, and Staphylococcus aureus. Viruses often isolated from infections of this nature are related to influenza strains, adenoviruses, and, more recently, SARS-CoV-2 (formerly known as 2019-nCoV). The elderly and people with underlying diseases are more prone to severe outcomes, apparently associated with acute respiratory distress syndrome (ARDS) and cytokine storm syndrome. [24,39].

Antimicrobials used in treating these diseases usually constitute high-cost drugs, causing infected patients to represent high direct and indirect medical expenses for the hospital. Therefore, there is a strong socioeconomic impact associated with hospitalization in infectious conditions, resulting in substantial and sometimes excessive costs associated with treatment, hospitalization, and absenteeism. [31,39]

One of the current strategies used to optimize the patient's therapeutic process and prevent injuries that lead to hospitalization is related to reducing the organism's inflammatory response, favoring the reduction in costs with treatment and hospitalization. The substances, extracted mainly from plant species, have promising particular pharmacological properties, which can actively participate in the treatment to improve clinical conditions and patient-related health problems (SCHNEIDER et al., 2018) ${ }^{[48] . ~ I n ~ t h i s ~}$ context, aromatherapy is a useful adjuvant therapeutic tool in this process. It is grounded in the synergistic action of mixing essential oils to heal the mind, body, and senses ${ }^{[31]}$.

\section{OBJECTIVES}

The present study proposes an integrative review of the literature on aromatherapy as a tool to be used in prophylaxis and therapy in respiratory system disorders.

\section{METHOD}

This study is an integrative review of the literature. The articles published in full in Portuguese and English, which portrayed the referent theme, published and indexed in the leading databases in the last ten years, except for the literature considered classical and fundamental, were considered valid. Thus, the analysis went through scientific articles published in six databases Virtual Health Library - Traditional, Complementary and Integrative Medicines (VHL MTCl Americas), Brazilian Integrative Health Consortium (CABSIN), Research Gate, Scientific Electronic Library Online (Scielo), MEDLINE, PubMed, using as descriptors the terms essential oil, respiratory disease, aromatherapy. The extracted data performed the analysis regarding the synthesis descriptively, making it possible to observe, describe, and interpret the data to 
gather the knowledge produced on the theme explored in this review.

\section{RESULTS AND DISCUSSION}

After passing the exclusion and content analysis criteria, 124 articles from the analysis performed in the databases narrowed to 44 .

\subsection{Inflammatory Processes and Respiratory Complications}

The respiratory process consists of an elaborate psycho-neuro-emotional interaction resulting in a physiological response of gas exchange involuntarily, linked to the autonomic nervous system. Impulses initiated by psychic or sensory stimulation of the cerebral cortex can affect breathing. Under normal conditions, the respiratory center (RC) can produce, every 5 seconds on average, an autonomous nerve impulse that stimulates the contraction of the thoracic musculature and diaphragm, making us inhale. This alignment is due to the refined control performed by receptors sensitive to the difference of gradient of concentration of $\mathrm{CO}_{2}, \mathrm{O}_{2}$, and changes in $\mathrm{pH}$ in the blood plasma, which allows regulating the amplitude of respiratory movements in search of homeostasis. From this reasoning, the conscious process of breath control can affect, in the opposite way to the autonomous stimulus, endogenous biochemical parameters bringing benefits such as the regulation of glycemic levels and the variability of heart rate. ${ }^{[47]}$.

The respiratory system comprises specialized structures that form the upper tract (nose, nasal cavity, mouth, pharynx, and larynx) and the lower tract (trachea, bronchi, bronchioles, and alveolus) that ensure refined processes involving breathing. Moreover, other structures aid in the defense against exogenous contaminants such as nasal hair, mucociliary cells, inflammatory phagocytic cells, and residual microbiota. When infecting agents overcome these defense barriers, there is tissue damage, and a series of cascading reactions are activated, releasing the hormone histamine and initiating the inflammatory process of response ${ }^{[14]}$.

The degranulation of mast cells releases histamine that plays an essential role in regulating the inflammatory process. This degranulation intends to attract leukocytes and proteins (cytokines) to the site of damage to destroy the etiological agent. Inflammatory mediators such as eicosanoids, especially prostaglandins and leukotrienes, are released to increase capillary permeability and vasodilation and access antibodies and immune cells ${ }^{[14,31]}$.

Patients with more severe infections, such as COVID-19, may suffer the consequences of cytokine storm syndrome (CTS), which requires therapeutic strategies that address the suppression of hyper inflammation characterized by a fulminant and lethal hypercytokinemia ${ }^{[34]}$.

Severe acute respiratory distress syndrome effects are related to secondary hemophagocytic lymphohistiocytosis (sHLH). They include persistent fever, cytopenias, and hyperferritinemia; pulmonary involvement occurs in approximately $50 \%$ of patients ${ }^{[34,51]}$.

These signs and symptoms are a consequence of the release of inflammatory mediators of type interleukin (IL)-2, IL-7, granulocyte-colony stimulating factor, interferon-yinducible protein 10 , monocyte chemoattractant protein 1, macrophage inflammatory protein $1-\alpha$, and tumor necrosis factor- $\alpha{ }^{[34,51]}$.

In this context, current studies have demonstrated as a promising therapeutic approach the use of anti-inflammatory and immunosuppressive substances, especially in the blockade of inflammatory mediators such as IL-6, IL-1, IFN- $\gamma$ TNF- $\alpha$ as an important therapeutic target for the treatment and prevention of serious complications resulting from respiratory tract diseases ${ }^{[34,46,51]}$.

\subsection{Absorptive pathways and physiological action of aromas in the body}


According to the concepts of aromatherapy, essential oils act by different routes and can act at the local, systemic, or central leve ${ }^{[31]}$. Local action can be obtained by topical/pulmonary administration route, administering on the skin with concentrated or diluted oils associated with massage to increase absorption. On the other hand, the administration of these oils on regions of the chest, back, and soles of the feet suggest treatments related to respiratory infections. Thus, dermal absorption occurs, in addition to pulmonary inhalation, favoring local and directed action. Despite the low topical absorption (5\%), the joint action of inhalation of aromas released in this form of use helps to drain secretions from the sinuses of the face and loosening of phlegm [35].

Another possibility of administration is the oral route, through the ingestion of hydrolats or formulations by encapsulation. In this case, the substances' bioavailability is approximately $95 \%$; however, this form of consumption presents a considerable degree of uncertainty regarding safety, not being advised by classical aromatherapy [31,35].

The pulmonary pathway is the most common in respiratory tract therapies, representing a complex pathway that can trigger different body actions (Figure 1).

Figure 1 - Absorption of essential oils from inhalation.

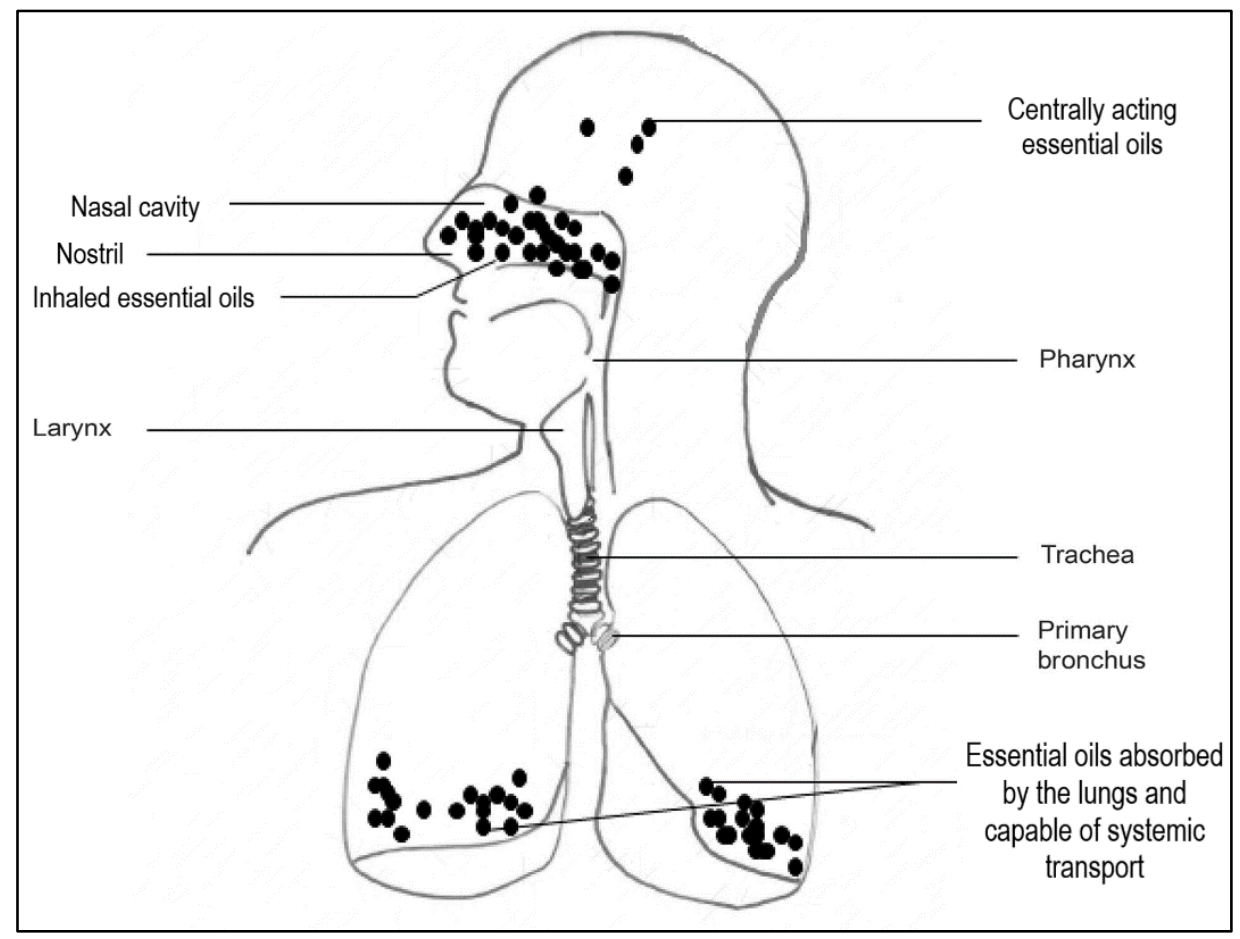

Source: Adapted from RAPPER and VUUREN, 2020.

The essential oils reach the nasal cavity after innated. They reach the lungs after going through the structures that make up the lower respiratory tract, where they are then absorbed and distributed systemically. The lungs can develop local actions due to the anti-inflammatory and antimicrobial potential of these substances, indicated in the oral cavity, throat, or even pulmonary inflammations ${ }^{[30,35]}$. These compounds reach the most intimate spaces and, due to their chemical characteristics and their effects on mucociliary clearance, can remain in these spaces for prolonged periods (HASANI et al., 2003).

At the same time, they can develop systemic activities due to the intense vascularization 
that this site presents. Also, pulmonary absorption represents a bioavailability of $50 \%$ ([31]. According to Boron and Boulpaep (2012) [5], olfactory receptor genes make up $3 \%$ of all genes, making them the largest family of genes in the human genome. The body contains tens of millions of olfactory receptor cells found in almost all organs, including the skin, brain, heart, and gastrointestinal tract ${ }^{[48]}$.

Considered as a chemical sense detected by chemoreceptors, the smell is activated when an odorizing substance stimulates receptors in the nose, transmitting electrical impulses to the brain ${ }^{[7]}$. Neurobiological research has shown that smell is an experience mediated by prefrontal processes. When odor molecules reach the nasal mucosa, neurons conduct the response to the olfactory bulb, triggering mid-level responses ${ }^{[22]}$.

It is essential to point out that the trigeminal system is also part of the nasal cavity and the olfactory system. Most odoriferous molecules stimulate both systems, which have consequences for the perception of odors and the somatosensory innervations associated with them (BRAND, 2006). Thus, the stimuli perceived by smell are not submitted to neuropsychological filtering processes because the rhinencephalon records them, directly relaying sensory information to the amygdala without projecting to the thalamus [32].

By activating specific limbic system areas, they can trigger physiological responses that control most of the body's vegetative and endocrine functions. This system characterizes the neuronal circuit, which is responsible for controlling emotional behavior. Observing the structures that make up the complex brain anatomy, the hypothalamus plays a fundamental role in controlling the limbic system, which presents a central strategic location. This structure is responsible for most vegetative and endocrine functions, in addition to many behavioral aspects (GUYTON, 2011). The amygdala and hippocampus are the main structures of the limbic system that directly participate in the perception of olfactory stimuli, which respectively confer emotion related to olfactory memory (Figure 2).

Figure 2 - Anatomical structures that make up the cerebral limbic system.

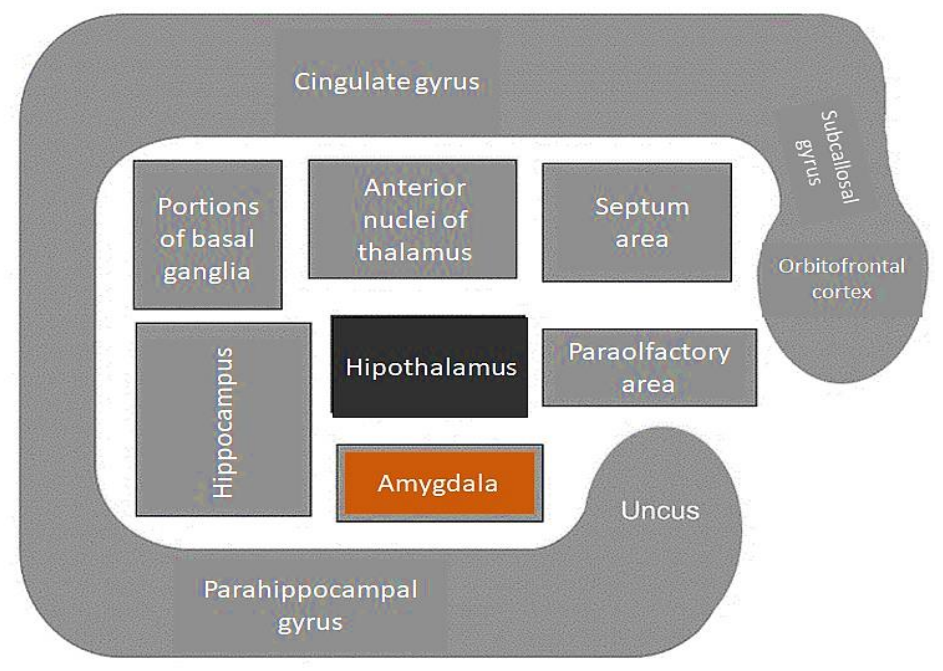

Source: Adapted from Guyton, 2011.

Hence, essential oils have particular aromas, such as peppermint oil, can alter pharmacological properties and can actively endogenous brain pathways to opioids, thus trigger physiological responses. Certain 
reducing pain, inflammation, anxiety, besides presenting antimicrobial effects ${ }^{[8,55]}$.

\subsection{Anti-inflammatory essential oils}

The inflammatory process consists of a complex physiological or even pathophysiological regulation related to the response of vascular tissues in defense against pathogens, cellular damage or irritation stilettos, or physical irradiation in order to eliminate the etiological agent ${ }^{[14]}$

Cytokines, such as interferons, interleukins, chemokines, mesenchymal growth factors, the tumor necrosis factor family, and adipokines, resulting from this process, play an essential physiological role in signaling and developing infectious pathogenic processes or even in the degenerative degradation resulting from the natural senility process. Since the inflammatory process involves complex regulatory networks, bioactive substances that control this metabolic chain's specific points have been present in numerous studies. ${ }^{[51]}$.

Essential oils have shown significant clinical interest due to several chemicals such as monoterpenes, sesquiterpenes, and phenylpropanoids. These substances are critical to pro-inflammatory biochemical processes' multimodal regulation through synergistic action ${ }^{[36]}$.

Studies show that the alcoholic acyclic sesquiterpene farnesol is one of these crucial biomolecules found in species such as citronella, lemongrass, and rose grass and known to function as a chemopreventive, antitumor, and anti-inflammatory agent. Preliminary studies in guinea pigs show a probable mechanism of action related to pulmonary protection and oxidative stress showing a significant reduction in lactate dehydrogenase (LDH) and malondialdehyde (MDA) levels in bronchoalveolar fluid lavage (BALF) in the total cell count when administered to guinea pigs at the dose of 50 and $100 \mathrm{mg} / \mathrm{kg}$, once a day for seven days [29].
Farnesol also significantly increased the reduced glutathione (GSH) content, minimized the reduced $\mathrm{H} 2 \mathrm{O} 2$ content, restored the levels of components of the redox enzyme cycle such as glutathione reductase (GR), glutathione peroxidase (GPx), and restored catalase levels in lung tissue, demonstrating a significant improvement in oxidative damage [28].

Another sesquiterpene highlighted by its antiinflammatory activity is the caryophyllene found in many essential oils, for example, the oil of the stems and flowers of Syzygium aromaticum (clove) [20], Cannabis sativa hemp essential oil [19] and Rosmarinus officinalis (rosemary) (ORMEÑO et al., 2008) [43]. Most commonly found in a mixture of $\alpha$-Humulene (obsolete name: $\alpha$-caryophyllene) has been reported for its biological activities, including anticarcinogenic due to its ability to increase the activity of Natural Killer cells in vitro and in vivo studies in addition to their participation in different anti-inflammatory pathways, including the cannabinoid receptor pathways [12].

Caryophile oxide, a derivative of this molecule, present in bark extracts of Annona squamosa L., an Indian plant used to treat rheumatism and pain in addition to known antipyretic, antiulcerogenic, antiseptic, analgesic, and anti-inflammatory properties. When administered to guinea pigs in pharmacological tests at a dose of $25 \mathrm{mg} / \mathrm{kg}$, an effect comparable to aspirin, a reference compound, was shown in a much higher dose $(100 \mathrm{mg} / \mathrm{kg})^{[10]}$

The anti-inflammatory modulation pathway through the endocannabinoid system involves a network of lipid signaling that modulates neuronal signals of stress-related downregulating, triggering inflammatory processes, and certain types of pain. Regarding endocannabinoid receptors, the CB2 receptors are responsible for the mediation of signs that attenuate the inflammatory process. 
Studies show that the selective binding of caryophyllene to CB2 receptors exerts a significant anti-inflammatory cannabimimetic effect in mice, showing potential therapeutic agents. Moreover, caryophyllene is responsible for inhibiting receptors (CD14/TLR4/MD2) involved in expressing inflammatory cytokines (IL-1 $\beta$, IL-6; IL-8 and TNF- $\alpha$ ) regarding the immunological response stimulus of Th1. The results also demonstrate inhibition of phosphorylation in macrophages and LPS-stimulated monocytes of Erk 1/2 kinases ${ }^{[3,23]}$.

The species Cordia verbenacea D.C. (Boraginaceae) is a widely used Brazilian medicinal plant as an anti-ulcerative, antimicrobial, anti-inflammatory antirheumatic, analgesic agent, and tonic. Its leaves have phytochemicals such as tannins and flavonoids. Furthermore, this species has various monoterpenes and sesquiterpenes, for instance: a-pinene, caryophyllene, alloaromadendrene, a-humulene, spathulenol, $\beta$-gurjunene, and caryophyllene oxide. Studies highlight the anti-inflammatory and analgesic properties mainly of $\alpha$ humulene and caryophyllene $(50 \mathrm{mg} / \mathrm{kg})$ as inhibitory agents of migration of proinflammatory and eicosanoid cells with activity similar to corticosteroids such as dexamethasone [17,33,44].

Among the potential phytochemicals for controlling inflammatory processes are also the bisabolol and chamazulene sesquiterpenes.

The bisabolol is a monocyclic alcoholic sesquiterpene found as a constituent of species such as German chamomile (Matricaria recutita) and Myoporum crassifolium where it has demonstrated its anti-inflammatory potential as a chemoprotection of mitochondrial integrity in breast tumors along with promoting downregulation of genes implicated in carcinogenesis and angiogenesis mechanism in rats ${ }^{[11,9]}$. Besides, this sesquiterpene has evidenced significant topical anti-inflammatory activity, promoting antioxidant protection by antagonizing the oxidative stress process [31].

The chamazulene compound comes from the metabolization of matricin in species such as Artemisia absinthium, Achillea millefolium, and Matricaria chamomilla. Promising activities have come up along with this compound as in inhibiting the synthesis of leukotrienes in neutrophilic granulocytes exhibiting antioxidant activity in addition to suppression of $\mathrm{LTB}_{4}$ inhibiting the oxidation process of arachidonic acid [13].

According to Jin et al. (2011), other sesquiterpenes such as valencene, nootkatone, and caryophyllene oxide exerted antiallergic activity in vitro and in vivo. The research shows promisingly that valencene (most active sesquiterpene) inhibits the degranulation of $\beta$-hexosaminidase through the Lyn phosphorylation reaction in IgEstimulated cells and RBL-2H3. Valencene and nootkatone sesquiterpenes also inhibited the late-type hypersensitivity reaction in rats when administered orally in the range of $50-300$ $\mathrm{mg} / \mathrm{kg}$.

In this context, sesquiterpenes appear as potential anti-inflammatory therapeutic agents with mechanisms of action involved in modulation or suppression of elements that play a direct role in inflammatory response and evidence both in vivo and in vitro experimental protocols.

\subsection{Antimicrobial action of essential oils}

Among the constant challenges for global public health, one can observe emerging and reemerging infectious diseases. Associated with this panorama, microbial resistance to the primary drugs used in modern clinical practice has been a growing phenomenon, evidencing the large increase in the number of studies that propose the search for new therapeutic options as an alternative [21].

The use of plants for medicinal purposes is one of the oldest forms of medicinal practice 
of humanity, seeing in them, especially in the essential oils present in their tissues, a potential source of biomolecules of interest in this field of research [56]. According to data related to research conducted by Rapper and Vuuren (2020) [31], the antimicrobial action of essential oils has been the target of many studies, considering them as a therapeutic possibility, observing more than 2,000 publications related to this theme in 2019 alone.

Essential oils demonstrate varied, complex mechanisms of antimicrobial effects dependent on the chemical constitution of this substance. Essential oils perform as substances arising from plant metabolism in the face of adaptive biological needs formed by a mixture of substances belonging to several different classes ${ }^{[52]}$. Thus, the way they perform the antimicrobial effect can be different for each type of oil. Also, the bacterial pathogen's anatomical structural characteristics can determine the different actions against different microorganisms ${ }^{[57]}$.

These compounds present as a mechanism of bacterial destruction of their cell structure's destabilization, resulting from membrane integrity breakdown. They act differently against Gram-positive and Gram-negative bacteria due to variations in bacterial cell wall density.

As they are lipophilic compounds by nature, they are absorbed more rapidly by grampositive strains due to their dense phospholipid bilayer within cell walls. Essential oils, therefore, trigger the antimicrobial effect by acting at the junction of the cell wall, as well as within the cytoplasm (ALVIANO et al., 2009) [2]. Increased cell permeability due to membrane damage prevents cellular activities such as energy production, membrane transport, metabolic regulation, and ion loss. In the cytoplasm, they demonstrated the ability to disturb the proton pump by decreasing intracellular ATP. These events' joint action causes cytoplasmic coagulation of internal cellular components, resulting in cell death ${ }^{[57]}$.

The antimicrobial action of essential oils suffers a higher resistance due to the differentiated cell wall nature of Gramnegative bacteria concerning Gram-positive bacteria. Porin channels responsible for transporting substances between intracellular and extracellular media are resistant to hydrophobic compounds' entry. Thus, essential oils are absorbed more slowly in the cells of these pathogens ${ }^{[40]}$.

According to the World Health Organization classification of pathogens with a higher incidence of respiratory infections [59], Streptococcus pyogenes is considered the most common Gram-positive pathogen in upper and lower respiratory tract infections, while $S$. aureus has limited pathogenesis. Regarding Gram-negatives, Haemophilus influenzae has the highest prevalence since Klebsiella pneumoniae presents itself as an uncommon pathogen responsible for nosocomial pneumonia infections. Studies conducted by Rapper and Vuuren (2020) [31] indicate an inverse relationship to the number of publications related to essential oils' effects against these strains of microorganisms. For the authors, microorganisms with the highest pathogenic incidence in respiratory infections have the least studies on essential oils' antimicrobial use (Figure 3).

These results point to the use of essential oils as a viable therapeutic alternative in modulating respiratory infections. Different antimicrobial susceptibility methods are available to determine activity, with varying degrees of reliability ${ }^{[18]}$.

Based on the results of different studies on antimicrobial tests with essential oils, the main plant species whose compounds act to combat respiratory infections caused by Haemophilus influenzae and Streptococcus pyogenes are: Cinnamomum zeylanicum, Citrus hystrix, Cymbopogon Citratus, Eucalyptus globulus, Eucalyptus odorata, Juniperus 
communis, Lavandula angustifólia, Lavandula piperita, Pinus sylvestris, Syzygium aromaticum intermedia, Melaleuca leucadendra, Mentha and Thymus vulgaris [1,4,15,16,26,41,50,54].

Figure 3 - Publications on the effects of essential oils on strains of microorganisms.

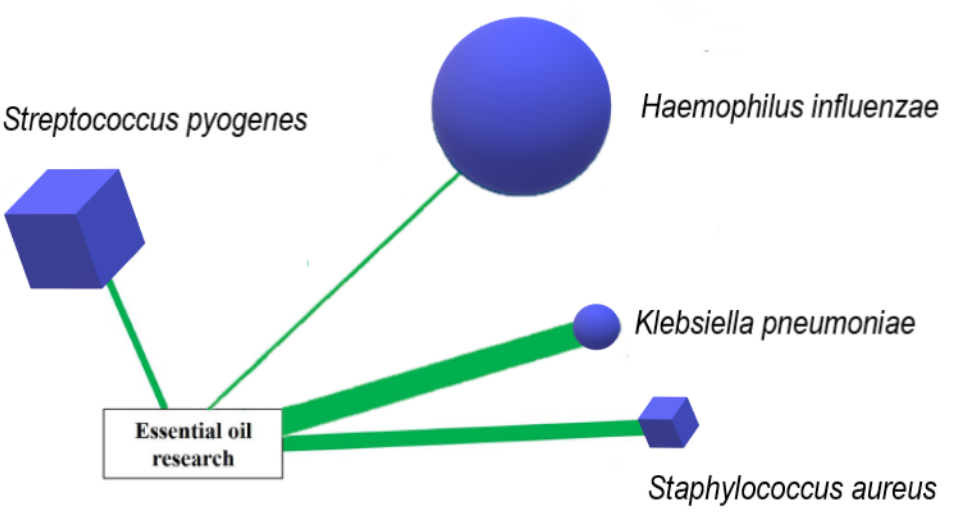

Gram-positive (cubes) and Gram-negative (spheres). Connection bar thickness (number of publications) and size of spatial geometric figures (prevalence of microorganism) refer to the intensity of the parameter analyzed-source: adapted from Rapper and Vuuren (2020) ${ }^{[31]}$.

\subsection{Antiviral Action of Essential Oils}

Lately, we have experienced a worldwide challenge in combating a viral infection capable of amitting the respiratory system. At the end of December 2019, several patients with pneumonia of unknown cause came up in Wuhan, Hubei Province, China [60]. Respiratory infections resulting from the new coronavirus have typical symptoms of the cold and fever but can lead to severe diseases such as MERS (Middle East Respiratory Syndrome) and SARS (Severe Acute Respiratory Syndrome) (ASIF et al., 2020).

Since the beginning of the pandemic, research on therapeutic possibilities has aroused the scientific class an urgent need to develop new protocols to achieve the necessary efficiency in combating this infection (OJAH, 2020). More than half of current therapies have a natural origin or have been motivated by natural product chemistry. More than $40 \%$ of the antibacterial, antifungal, antiviral, or anticancer molecules developed by the pharmaceutical industry have a natural origin (HARVEY, 2007) ${ }^{[27] .}$

The search for new antiviral clinical treatments, in particular, given the global panorama, has led science to observe essential oils as potentially useful antiviral agents, given their known action against various human pathogenic viruses and other respiratory diseases caused by viral infections (PATNE et al., 2020) [31]. These substances are considered active against a wide variety of viruses, such as influenza virus (IFV), human herpesvirus (HSV), human immunodeficiency virus (HIV), yellow fever virus, and avian influenza (MA and YAO 2020) [31].

Few studies have led to the mechanism of antiviral action of essential oils (SWAMY et al., 2016) ${ }^{[31]}$, not being well established according to the scientific literature. According to HAYASHI et al. (1993) [31], the phenylpropanoids present in essential oils can 
inhibit the formation of the virion wrap necessary for its entry into host cells and preventing viral replication by inhibiting cellular DNA polymerase.

Viruses present a complex challenge to the essential oils' action since some of these pathogens are involved in a capsule while others are not. Those with viral capsules are often more resistant to essential oils' lipophilic nature, representing a challenge in preventing cell contamination. The most prevalent viruses in respiratory infection are rhinovirus, parainfluenza virus, coronavirus, adenovirus, respiratory syncytial virus, coxsackievirus, human metapneumovirus, and influenza virus (RAPPER and VUUREN, 2020) [31].

According to the results obtained on the main plant species with antiviral potential, we can mention: Allium sativum, Artemisia glalabela, Cinnamomum camphora, Cinnamomum verum, Citrus bergamia, Citrus limonum, Cupressus sempervirens, Cymbopogon citrates, Eucalyptus globulus, Foeniculum vulgare, Houttuynia cordata, Juniperus communis, Juniperus oxycedrus, Laurus nobilis, Lavandula latifólia, Melissa officinalis, Mentha alternifolia, Mentha piperita, Ocimum basilicum album, Origanum acutidens, Origanum majorana, Origanum vulgare, Ravensara aromatica, Rosmarinus officinalis, Salvia limbata, Theileria orientalis and Thymus vulgaris (HAYASHI et al., 1995; MINAMI et al., 2003; ÖĞÜTÇÜ et al., 2008; PATNE et al., 2020; RAPPER and VUUREN, 2020; SEIDAKHMETOVA et al., 2002; SÖKMEN et al., 2004) [31,37,42,45,49,53]

\section{CONCLUSION}

Several studies have demonstrated the potential of using essential oils alone or combined with oils of other species, both in vitro and in vivo, as a strategy for the prevention of respiratory diseases and potentiation of classical therapies. This strategy is possible due to the synergistic effects of substances with bioactive potential such as sesquiterpenes, monoterpenes, and phenylpropanoids. Thus, it is evident the need for in-depth knowledge of patients' clinical parameters, the possibilities of pharmacokinetic and pharmacodynamic interactions that these substances can promote, potential risks of toxicity, and clinical efficacy. Thus, robust studies involving chemistry, clinical trials, studies of mechanisms of action, antiinflammatory, and antioxidant activities are necessary to bring confidence to the professional in managing injuries and comfort to the patient submitted to therapy-based value with a safe prognosis.

\section{REFERENCES}

1. ÁCS, K.; BALÁZS, V.L.; KOCSIS, B.; BENCSIK, T.; BÖSZÖRMÉNYI, A.; HORVÁTH, G. Antibacterial activity evaluation of selected essential oils in liquid and vapor phase on respiratory tract pathogens', BMC Complement. Alternat. Med. 18: 227. 2018.

2. ALVIANO, D.S.; ALVIANO, C.S. Plant Extracts: Search for New Alternatives to Treat Microbial Diseases', Curr. Pharm. Biotechnol. 10: 106-121. 2009.

3. ASHTON JC. Cannabinoids for the treatment of inflammation. Current Opinion in Investigational Drugs, 8, 373-384. 2007.

4. BLAŽEKOVIĆ, B.; YANG, W.; WANG, Y.; LI, C.; KINDL, M.; PEPELJNJAK, S.; VLADIMIRKNEŽEVIĆ, S. Chemical composition, antimicrobial and antioxidant activities of essential oils of Lavandula $x$ intermedia 'Budrovka' and L. angustifólia cultivated in Croatia', Ind. Crops Prod. 123: 173-182. 2018.

5. BORON, W.F.; BOULPAEP, E.L. 2012. Medical physiology. Oxford: Elsevier.

6. BRAGA PC, DAL SASSO M, FONTI E, CULICI M. Antioxidant activity of bisabolol: inhibitory effects on chemiluminescence of human neutrophil bursts and cell-free systems. Pharmacology, 83, 110-115. 2009.

7. BUCK, L.; AXEL, R. A novel multigene family may encode odorant receptors: A molecular basis for odor recognition. Cell 65(1):175-187. 1991.

8. BUSHNELL, M.C.; CEKO, M.; LOW, L.A. Cognitive and emotional control of pain and its disruption in chronic pain. Nature Reviews Neuroscience. 14: 502-511. 2013.

9. CAVALIERI E., RIGO A., BONIFACIO M., CARCERERI DE PRATI A., GUARDALBEN E, BERGAMINI C, FATO R, PIZZOLO G, SUZUKI H, VINANTE F. Pro-apoptotic activity of $\alpha$-bisabolol in preclinical models of primary 
Alan Lucena de Vasconcelos et al., IJBM, 2021; 4:15

human acute leukemia cells. Journal of Translation Medicine, 9, 45. 2011.

10. CHAVAN MJ, WAKTE PS, SHINDE DB. Analgesic and anti-inflammatory activity of caryophyllene oxide from Annona squamosa L. bark. Phytomedicine, 17, 149-151. 2010.

11. COSTARELLI L, MALAVOLTA M, GIACCONI $\mathrm{R}$, CIPRIANO C, GASPARINI N, TESEI S, PIERPAOLI S, ORLANDO F, SUZUKI $\mathrm{H}$, PERBELLINI L. In vivo effect of alphabisabolol, a nontoxic sesquiterpene alcohol, on the induction of spontaneous mammary tumors in HER-2/neu transgenic mice. Oncology Research, 18, 409-418. 2010.

12. DA SILVA SL, FIGUEIREDO PM, YANO T. Chemotherapeutic potential of the volatile oils from Zanthoxylum rhoifolium Lam leaves. European Journal of Pharmacology, 8, 180188. 2007

13. DA SILVEIRA E SÁ, R. D. C., ANDRADE, L. N., DE SOUSA, D. P. Sesquiterpenes from essential oils and anti-inflammatory activity. Nat. Prod. Commun. 10, 1767-1774. 2015.

14. D'ALMEIDA TELLES FILHO, P. Asma Brônquica Mediadores Lipídicos Leucotrienos. Avaliable at <http://www.asmabronquica.com.br/medical/ mediadores_lipidicos.html >. Accessed on 11/20/2020.

15. ELAISSI, A.; ROUIS, Z.; SALEM, N.A.B; MABROUK, S.; SALEM, Y. B.; SALAH, K.B.H.; AOUNI, M.; FARHAT, F.; CHEMLI, R.; HARZALLAH-SKHIRI, F.; KHOUJA, M.L. Chemical composition of 8 eucalyptus species' essential oils and the evaluation of their antibacterial, antifungal and antiviral activities', BMC Complement. Alternat. Med. 12: 81. 2012.

16. FABIO, A.; CERMELLI, C.; FABIO, G.; NICOLETTI, P.; QUAGLIO, P. Screening of the Antibacterial Effects of a Variety of Essential Oils on Microorganisms Responsible for Respiratory Infections', Phytother. Res. 21: 374-377. 2007.

17. FIDYT, K., FIEDOROWICZ, A., STRZĄDAŁA, L., SZUMNY, A. B-Caryophyllene and BCaryophyllene Oxide-Natural Compounds of Anticancer and Analgesic Properties. Cancer Med. 5, 3007-3017.2016.

18. FRIEDMAN, M.; HENIKA, P.R.; MANDRELL, R.E. Bactericidal Activities of Plant Essential Oils and Some of Their Isolated Constituents against Campylobacter jejuni, Escherichia coli, Listeria monocytogenes, and Salmonella enterica', J. Food Prot. 65: 1545-1560. 2002.
19. GERTSCH J, LEONTI M, RADUNER S, RACZ I, CHEN JZ, XIE XQ, ALTMANN KH, KARSAK M, ZIMMER A.Beta-caryophyllene is a dietary cannabinoid. Proceedings of the National Academy of Sciences, 105, 9099-9104. 2008.

20. GHELARDINI C, GALEOTTI N, DI CESARE MANNELLI L, MAZZANTI G, BARTOLINI A. Local anaesthetic activity of betacaryophyllene. Farmaco, 56,387-389. 2001.

21. GHOLAM-REZA T.; MOHSEN M.; MAHMOUD B.; MAHMOUD R. K. Synergistic effect of Carum copticum and Mentha piperita essential oils with ciprofloxacin, vancomycin, and gentamicin on Gram-negative and Gram-positive bacteria. International Journal of Pharmaceutical Investigation. 7(2): 82-87. 2017.

22. GOTTFRIED, J. Smell: Central nervous processing. In: HUMMEL, T.; WELGELÜSSEN, A. Taste and smell. An update. Basel: Karger. 295-307. 2006.

23. GUINDON J, HOHMANN AG. Cannabinoid CB2 receptors: a therapeutic target for the treatment of inflammatory and neuropathic pain. British Journal of Pharmacology, 153, 319-334. 2008.

24. GUO, Y.; CAO, Q.; HONG, Z., et al. The origin, transmission and clinical therapies on coronavirus disease 2019 (COVID-19) outbreak - an update on the status. Military Med Res. 7: 11. 2020.

25. GUYTON, A.C; HALL, J.E. Tratado de Fisiologia Médica. 12ed. Rio de Janeiro.Elsvier; 2011. 1176p.

26. HAMOUD, R.; SPORER, F.; REICHLING, J.; WINK, M. Antimicrobial activity of a traditionally used complex essential oil distillate (Olbas $®$ Tropfen) in comparison to it's individual essential oil ingredients', Phytomedicine. 19: 969-976. 2012.

27. HARVEY AL. Natural products as a screening resource. Curr Opin Chem Biol. 11(5):480-4. 2007.

28. JAHANGIR T, KHAN TH, PRASAD L, SULTANA S. Farnesol prevents Fe-NTA mediated renal oxidative stress and early tumour promotion markers in rats. Human \& Experimental Toxicology, 25, 235-242. 2006.

29. JAIMES EA, DE MASTER EG, TIAN RX, RAIJ

L. Stable compounds of cigarette smoke induce endothelial superoxide anion production via NADPH oxidase activation. Arteriosclerosis, Thrombosis, and Vascular Biology, 24, 1031-1036. 2004. 
30. KIEŁTYKA-DADASIEWICZ, A.; GORZEL, M. Alternative therapies. Aromatherapy - raw materials and treatments. Eur J Med Technol, 1(2):72-79. 2014.

31. LEIGH-DE RAPPER, S. \& VAN VUUREN, S. F. Odoriferous Therapy: A Review Identifying Essential Oils against Pathogens of the Respiratory Tract. Chem. Biodivers. 17, (2020).

32. MASAOKA, Y., \& HOMMA, I. Breathing for olfaction and emotion. In L. E. Weiss, \& J. M. Atwood (Eds.), The biology of odors, sources, olfaction and response (pp. 295-307). New York: Novapublishers. 2011.

33. MEDEIROS R, PASSOS GF, VITOR CE, KOEPP J, MAZZUCO TL, PIANOWSKI LF, CAMPOS MM, CALIXTO JB. Effect of two active compounds obtained from the essential oil of Cordia verbenacea on the acute inflammatory responses elicited by LPS in the rat paw. British Journal of Pharmacology, 151, 618-627. 2007.

34. MEHTA, P. et al. COVID-19: consider cytokine storm syndromes and immunosuppression. Lancet. 395: 1033-1034. 2020.

35. MICHALAK, M. Aromatherapy and methods of applying essential oils. Arch Physiother Glob Res. 22 (2): 25-31. 2018.

36. MIGUEL, M. G. Antioxidant and antiinflammatory activities of essential oils: A short review. Molecules 15, 9252-9287. 2010.

37. MINAMI, M.; KITA, M.; NAKAYA, T.; YAMAMOTO, T.; KURIYAMA, H.; IMANISHI, $J$. The inhibitory effect of essential oils on herpes simplex virus type- 1 replication in vitro. Microbiol Immunol. 47(9): 681-684. 2003.

38. MOREIRA, É. T., NUNES, T. F., SANTOS, E. DA S., CALLES, A. C. DO N. Perfil E Gravidade Dos Pacientes Admitidos Em Unidades De Terapia Intensiva: Uma. Cad. Grad. - Ciências Biológicas e da Saúde 1, 45522013.

39. NANGINO, G. DE O., OLIVEIRA, C. D. DE, CORREIA, P. C., MACHADO, N. DE M. \& DIAS, A. T. B. Impacto financeiro das infecções nosocomiais em unidades de terapia intensiva em hospital filantrópico de Minas Gerais. Rev. Bras. Ter. Intensiva 24, 357-361 (2012).

40. NAZZARO, F.; FRATIANNI, F.; DE MARTINO, L.; COPPOLA, R.; DE FEO, V. Effect of Essential Oils on Pathogenic Bacteria. Pharmaceuticals. 6: 1451-1474. 2013.

41. NIKOLIĆ, M.; JOVANOVIĆ, K.K.; MARKOVIĆ, T.; MARKOVIĆ, D.; GLIGORIJEVIĆ, N.; RADULOVIĆ, S.; SOKOVIĆ, M. Chemical composition, antimicrobial, and cytotoxic properties of five Lamiaceae essential oils', Ind. Crops Prod. 61 225-232. 2014.

42. ÖĞÜTÇÜ, H.; SÖKMEN, A.; SÖKMEN, M.; POLISSIOU, M.; SERKEDJIEVA, J.; DAFERERA, D.; et al. Bioactivities of the Various Extracts and Essential Oils of Salvia limbata CA Mey. and Salvia sclarea L. Turk J Biol. 32(3):181-92. 2008.

43. ORMEÑO E, BALDY V, BALLINI C, FERNANDEZ C. Production and diversity of volatile terpenes from plants on calcareous and siliceous soils: effect of soil nutrients. Journal of Chemical Ecology, 34, 1219-1229. 2008.

44. PASSOS GF, FERNANDES ES, CUNHA FM, FERREIRA J, PIANOWSKI LF, CAMPOS MM, CALIXTO JB. Anti-inflammatory and antiallergic properties of the essential oil and active compounds from Cordia verbenacea. Journal of Ethnopharmacology, 110, 323-333. 2007

45. PATNE, T.; MAHORE, J.; TOKMURKE, P. Inhalation of essential oils: could be adjuvant therapeutic strategy for Covid-19. Int J Pharm Sci \& Res. 11(9): 4095-03. 2020.

46. QUINTANS, J.S.S.; et al. Food and Chemical Toxicology, Elsevier. 123: 233-257. 2019.

47. SBISSA, P. P. M. Efeito Da Respiração Controlada E Da Meditação Mindfulness Sobre A Variabilidade Da Frequência Cardíaca. Universidade Federal de Santa Catarina 8, 44. 2014.

48. SCHNEIDER, R.; SINGER, N.; SINGER, T. Medical aromatherapy revisited-Basic mechanisms, critique, and a new development. Hum Psychopharmacol Clin Exp. 2018.

49. SEIDAKHMETOVA, R.B.; BEISENBAEVA, A.A.; ATAZHANOVA, G.A.; SULEIMENOV, E.M.; PAK, R.N.; KULYYASOV, A.T.; et al. Chemical Composition and Biological Activity of the Essential Oil from Artemisia glabella. Pharm Chem J. 36:135-8. 2002.

50. SFEIR, J.; LEFRANÇOIS, C.; BAUDOUX, D.; DERBRÉ, S.; LICZNAR, P. In Vitro Antibacterial Activity of Essential Oils against Streptococcus pyogenes', Evid.-Based Complement. Alternat. Med. 2013.

51. SHIMABUKURO-VORNHAGEN, A. et al. Cytokine release syndrome. J. Immunother. Cancer. 6. 2018.

52. SIMÕES, C.M.O.; SCHENKEL, E.P.; MELLO, J.C.P.; MENTZ, L.A.; PETROVICK, P.R. Farmacognosia: Do Produto Natural ao Medicamento. Artmed Editora, 2017. 
53. SÖKMEN, M.; SERKEDJIEVA, J.; DAFERERA, D.; GULLUCE, M.; POLISSIOU, M.; TEPE, B.; et al. In vitro antioxidant, antimicrobial, and antiviral activities of the essential oil and various extracts from herbal parts and callus cultures of Origanum acutidens. J Agric Food Chem. 52(11): 33093312. 2004.

54. SRISUKH, V.; TRIBUDDHARAT, C.; NUKOOLKARN, V.; BUNYAPRAPHATSARA, N.; CHOKEPHAIBULKIT, K.; PHOOMNIYOM, S.; SRIFUENGFUNG, S. Antibacterial activity of essential oils from Citrus hystrix (makrut lime) against respiratory tract pathogens', ScienceAsia. 38, 212-217. 2012.

55. SUN, Z.; WANG, H.; WANG, J.; ZHOU, L.; YANG, P. Chemical Composition and AntiInflammatory, Cytotoxic and Antioxidant Activities of Essential Oil from Leaves of Mentha piperita Grown in China. PLoS One. 2014.

56. SUROOWAN, S. MAHOMOODALLY, M.F. Alternative Antimicrobials from Natural Products Against Dermatological Infections. In: The Microbiology of Skin, Soft Tissue, Bone and Joint Infections. Academic Press: 2: 185204. 2017.

57. SWAMY, M.K.; AKHTAR, M.S.; SINNIAH, U.R. Antimicrobial Properties of Plant Essential Oils against Human Pathogens and Their Mode of Action: An Updated Review', Evid.-Based Complement. Alternat. Med. 2016.

58. VAUTRIN, A.; MANCHON, L.; GARCEL, A.; CAMPOS, N.; LAPASSET, L.; LAAREF, A.M.; BRUNO, R.; GISLARD, M.; DUBOIS, E.; SCHERRER, D.; EHRLICH, J.H.; TAZI, J. Both anti-inflammatory and antiviral properties of novel drug candidate ABX464 are mediated by modulation of RNA splicing. Sci Rep. 28, 9(1):792. 2019.

59. WORLD HEALTH ORGANIZATION - WHO. Protocol for the investigation of acute respiratory illness outbreaks of unknown etiology. Regional Office for Africa. Brazzaville: 2015.

60. ZHU, N. et al. A novel Coronavirus from patients with pneumonia in China, 2019. N Eng J Med. 1-7. 2020. 